\title{
Review
}

Basic Research

Diabetes Metab J 2020;44:509-528

https://doi.org/10.4093/dmj.2020.0058

pISSN 2233-6079 · eISSN 2233-6087

DIABET\&S \& METABOLISM JOURNAL

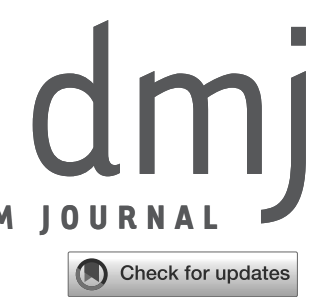

\section{Consequences of Obesity on the Sense of Taste: Taste Buds as Treatment Targets?}

\author{
Kerstin Rohde ${ }^{1}$, Imke Schamarek², Matthias Blüher ${ }^{1,2}$ \\ ${ }^{1}$ Helmholtz Institute for Metabolic, Obesity and Vascular Research (HI-MAG) of the Helmholtz Center Munich at the University of Leipzig and University \\ Hospital Leipzig, Leipzig, \\ ${ }^{2}$ Medical Department III (Endocrinology, Nephrology and Rheumatology), University of Leipzig, Leipzig, Germany
}

Premature obesity-related mortality is caused by cardiovascular and pulmonary diseases, type 2 diabetes mellitus, physical disabilities, osteoarthritis, and certain types of cancer. Obesity is caused by a positive energy balance due to hyper-caloric nutrition, low physical activity, and energy expenditure. Overeating is partially driven by impaired homeostatic feedback of the peripheral energy status in obesity. However, food with its different qualities is a key driver for the reward driven hedonic feeding with tremendous consequences on calorie consumption. In addition to visual and olfactory cues, taste buds of the oral cavity process the earliest signals which affect the regulation of food intake, appetite and satiety. Therefore, taste buds may play a crucial role how food related signals are transmitted to the brain, particularly in priming the body for digestion during the cephalic phase. Indeed, obesity development is associated with a significant reduction in taste buds. Impaired taste bud sensitivity may play a causal role in the pathophysiology of obesity in children and adolescents. In addition, genetic variation in taste receptors has been linked to body weight regulation. This review discusses the importance of taste buds as contributing factors in the development of obesity and how obesity may affect the sense of taste, alterations in food preferences and eating behavior.

Keywords: Dysgeusia; Feeding behavior; Food preferences; Obesity; Taste; Taste buds; Taste perception

\section{INTRODUCTION}

Obesity is defined as an excessive and abnormal storage of fat which can cause pathological conditions. Obesity increases the risk to develop type 2 diabetes mellitus, cardiovascular diseases, hypertension, fatty liver disease, sleep apnea, osteoarthritis, dyslipidemia, certain types of cancer, disruption of endocrine circuits, and low-grade systemic inflammation [1]. Although multiple factors contribute to the development of obesity, one crucial mechanism implicated is a profound mismatch between calorie intake and expenditure. In the westernized world, the need to engage in physical active behavior is vanishing whereas at the same time caloric dense food is constantly available. Food intake no longer fulfills the mere function of nourishment and sustaining physiological integrity and function but serves to satisfy hedonic needs. Hedonic food intake, hence the consumption of food for its palatability and related "pleasure" is fueled by flavor, which is the result of a complex interplay of sensory perception in which taste comprises an important role [2]. Therefore, the sense of taste plays a central role in the development of obesity as it contributes to food selection, caloric intake and consequently body weight regula-
Corresponding authors: Kerstin Rohde (D) https://orcid.org/0000-0001-5316-6870 Helmholtz Institute for Metabolic, Obesity and Vascular Research (HI-MAG) of the Helmholtz Center Munich at the University of Leipzig and University Hospital Leipzig, Philipp-Rosenthal-Straße 27, 04103 Leipzig, Germany

E-mail: Kerstin.Rohde@helmholtz-muenchen.de

Matthias Blüher (D) https://orcid.org/0000-0003-0208-2065

Helmholtz Institute for Metabolic, Obesity and Vascular Research (HI-MAG) of the Helmholtz Center Munich at the University of Leipzig and University Hospital Leipzig, Philipp-Rosenthal-Straße 27, 04103 Leipzig, Germany

E-mail: bluma@medizin.uni-leipzig.de

Received: Mar. 13, 2020; Accepted: Mar. 25, 2020
This is an Open Access article distributed under the terms of the Creative Commons Attribution Non-Commercial License (https://creativecommons.org/licenses/by-nc/4.0/) which permits unrestricted non-commercial use, distribution, and reproduction in any medium, provided the original work is properly cited. 
tion (Fig. 1).

Indeed, accumulating evidence connects taste to food selection and obesity [3-5]. People with obesity display decreased taste sensitivity [6,7]. Intriguingly, it appears that taste does not only contribute to obesity, but is also affected by obesity as accumulating evidence suggests that the primary taste tissue, the tongue, is an obesity target organ $[8,9]$. For example, the adipokine leptin is involved in sweet sensation of sweet sensing taste cells $[10,11]$. Importantly, obesity has been linked to a about $25 \%$ reduction in taste bud abundancy [9]. Alterations in taste sensation and taste buds may become a novel target for urgently needed obesity prevention and treatment strategies. Therefore, this review discusses the current understanding of how the sense of taste is regulated on the level of taste buds and how this modulates food intake in obesity. We also highlight that obesity itself may affect the sense of taste by distinct molecular mechanisms.

\section{THE SENSE OF TASTE}

The ingestion of food leads to a converging sensory perception which humans experience as a wide array of flavors, encoded

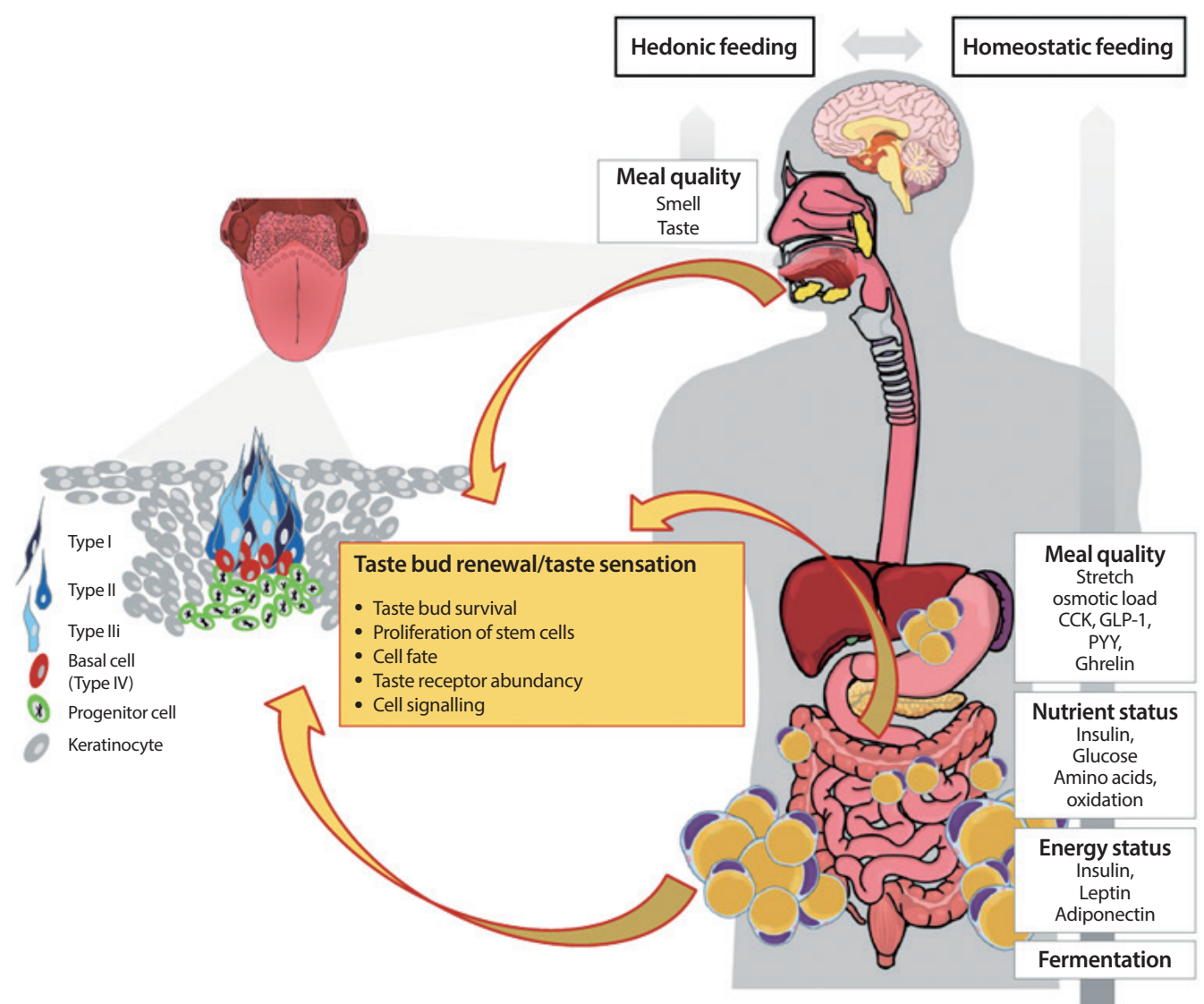

Fig. 1. Effects of obesity on the sense of taste and its relation to food intake. Food intake is driven by the interplay of hedonic and homeostatic feedback. During digestion, a variety of factors (meal quantity, nutrients, energy status, fermentation) feedback the nutrient load and energy status of the body towards the brain and control hunger and satiety circuits. However, the earliest signal priming the cephalic phase response is food quality reflected by smell and taste, which, moreover is the key driver for the reward driven hedonic eating. The earliest signals of food intake are processed in taste buds located on the tongue surface. Taste buds are very complex and consist of three functional taste cells (type I, type II, type III) and basal cells which can develop into either adult taste cell. Basal cells are post-mitotic cells which derive from proliferating progenitor cells clustering outside the taste bud and ensuring a lifelong cell turnover. Obesity is associated with alterations in taste sensation. This may be partially explained by the contribution of obesity on taste bud signaling, homeostasis and renewal. Thereby, the huge variety of factors potentially influencing the sense of taste on the level of taste buds (adipokines, cytokines, hormones etc.) may derive from the circulation, but also the salivary glands, local fat cells or even endocrine taste cells. CCK, cholecystokinin; GLP-1, glucagon like peptide 1; PYY, peptide YY. 
by the sense of taste. Although an uncountable range of flavors exists, it is generally accepted that only five taste qualities can be perceived by humans, namely sweet, sour, bitter, salty, and umami $[12,13]$. Nevertheless, the existence of "fatty" as a sixth taste quality is controversially discussed [14]. Taste perception commences when molecules from food (tastants) reach taste buds. Humans usually have 5,000 to 10,000 taste buds which are mainly, but not exclusively embedded in the epithelium of the tongues surface [15]. However, some taste buds are also present on the palate, epiglottis, pharynx, and esophagus [1618]. Lingual taste buds cluster into gustatory papillae which are categorized into papillae vallate, foliatae, and fungiformis according to their shape. They are located at the posterior, at the posterior-lateral sides and the anterior two-thirds of the tongue, respectively [19]. While papillae vallate accommodate hundreds of taste buds, papillae foliatae express around 50 and papillae fungiformis 3 to 5 taste buds [15]. Each taste bud is comprised of approximately 50 to 100 taste bud cells (TBCs) which are chemosensory cells of epithelial origin [20]. TBC can be categorized into three different cell types according to functional and structural features including patterns of protein expression (Fig. 2) [15].

All types of cells are present in each taste bud, with type I cells comprising roughly $50 \%$, and type II and type III cells contribute $15 \%$ to $20 \%$ each [15]. In recent years, taste perception has been very well characterized. Here, we focus on the major tasks of the diverse taste cells rather than describing detailed signaling mechanisms which have been recently reviewed elsewhere [15].

Type I cells mainly serve for the maintenance of the supporting structure of the taste bud. They display cytoplasmatic lamellar processes which enfold the other cells comprising the taste bud [21]. This is believed to regulate molecules involved in cell signaling by reducing their dispersion such as clearing spare neurotransmitter level secreted from type II and type III cells or buffer $\mathrm{K}^{+}$(potassium) by expressing cognate ion channels [22-24].

Type II cells are responsible for the perception of sweet, bitter, and umami taste via binding of tastants to G-protein coupled receptors (GPCR) [25,26]. These receptors function as monomers or dimers. Sweet tastants bind to receptor type 1 member 2 (T1R2 or TAS1R2) and member 3 (T1R3 or TAS1R3), but beside this well recognized mechanism, T1R-independent mechanisms appear to be implicated in sweet taste recognition $[27,28]$. Thus, glucose transporter type 4 (GLUT4) and sodium/ glucose transporter 1 (SGLT1) have been identified for transporting glucose into type II cells which results in the depolarization of the taste cell. This may be primarily of relevance for the cephalic phase insulin response, preparing for incoming food rather than signaling taste per se [27]. Heterodimers of T1R1 and T1R3 serve as receptor for the detection of L-glutamate (rodents) and L-aspartate (humans) and are recognized as umami $[29,30]$. The presence of glutamate receptors has been demonstrated to be important for the response to ingested glutamate in mice [31]. Bitter taste is sensed by T2Rs (or TAS2Rs) which comprises 25 receptor encoding genes in humans giving a hint for the various compounds stimulating bitter taste [32]. In contrast to T1Rs, only one type of bitter taste receptor is expressed per taste cell pointing towards the enormous role to distinguish diverse bitter compounds in contrast to just detect nutritious, sweet and savory food [33]. A single type II cell mainly responds to one specific taste quality forming separate populations of type II cells. However, this does not imply that the taste of a specific quality is restricted to a certain location on the tongue, as each taste bud located anywhere on the tongue harbors sweet, umami and bitter type II cells [13]. Despite their diversity, T1Rs and T2Rs both activate gustducin subunits when being stimulated by a tastant which further stimulate phospholipase $\mathrm{C} \beta 2$ and raise the intracellular $\mathrm{Ca}^{2+}$ level [34]. This results in opening transient receptor potential cation channel subfamily M member 5 (TRPM5) followed by a subsequent depolarization of taste cells. The latter process occurs by atypical and non-vesicular secretion of adenosine triphosphate (ATP) through calcium homeostasis modulator protein 1 (CALHM1) activating afferent nerve fibers [34-36]. Secreted ATP feeds back to type II cells in order to push further signaling or to stimulate type III cells [37]. Additionally, acetylcholine (Ach) is secreted by type II cells and serves as autocrine mediator for the secretion of ATP [38]. A degradation of extracellular ATP to adenosine diphosphate (ADP) is mediated enzymatically by ectonucleoside triphosphate diphosphohydrolase 2 (NTPDase2) in type I cells, which in turn increases the response to sweet stimuli by binding of ADP to adenosine $2 \mathrm{~B}$ (A2B) receptors in type II cells [39].

Type III cells, are referred to as presynaptic, neuron-like cells, as they form ordinary, neuronal synapses with afferent nerve fibers at the basal side of a taste bud. These cells release common neurotransmitters such as gamma aminobutyric acid (GABA), serotonin (5-HT) and noradrenaline upon depolarization via voltage gated $\mathrm{Ca}^{2+}$ channels $[25,40]$. In addition to secreted ATP 


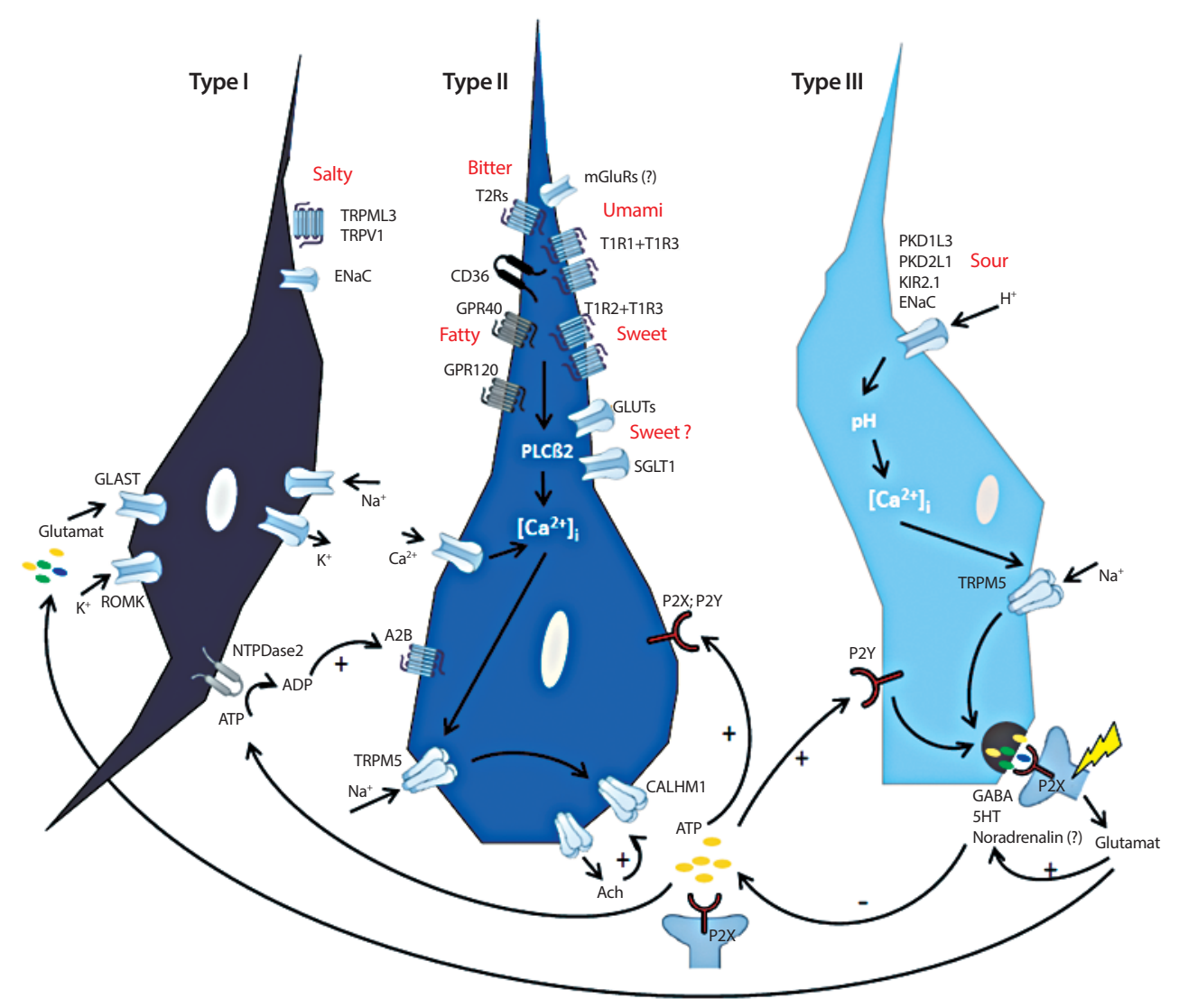

Fig. 2. Schematic presentation of cell signaling within taste bud cells. Type II cells express G-protein coupled receptors (GPRs) for bitter (taste receptors type 2 [T2Rs]), sweet (taste receptor type 1 member 1 [T1R1], T1R2, T1R3) and umami (T1R1+T1R3), but also GPR40 and 120 and glycoprotein 4 (also named cluster of differentiation 36, CD36) transducing the taste quality "fatty" [15]. In addition, metabotropic glutamate receptors (mGluRs) and glucose- and sodium/glucose transporters (GLUTs, SGLT1) are thought to transduce umami and sweet, respectively [27,31]. Binding of tastants to their cognate receptors increase intracellular calcium level $\left(\left[\mathrm{Ca}^{2+}\right]_{\mathrm{i}}\right)$ which activates transient receptor potential cation channel subfamily M member 5 (TRPM5), a Ca ${ }^{2+} / \mathrm{Na}^{+}$ cotransporter [34]. This leads finally to an activation of the calcium homeostasis modulator protein 1 (CALHM1) which is meant to release adenosine triphosphate (ATP) [35,36]. ATP signals to afferent nerve fibers via binding to P2X receptors but also feeds back in an autocrine fashion via binding to P2X and P2Y receptors on type II cells [36]. In addition, type II cells secrete Acetylcholine (Ach) which further stimulates ATP secretion [38]. Moreover, ATP activates type III cells by binding to P2Y receptors [37]. This in turn initiates the release of neurotransmitters gamma aminobutyric acid (GABA), serotonin (5-HT) and noradrenaline into the presynaptic space as consequence of raised $\left[\mathrm{Ca}^{2+}\right]_{\mathrm{i}}[25,40]$. In addition, this release is mediated as a result of changes in $\mathrm{pH}$ through the uptake of $\mathrm{H}^{+}$by ion channels such as polycystic kidney disease proteins 1 like 3 and 2 like 1 (PKD1L3, PKD2L1), inward rectifying $\mathrm{K}^{+}$channel (KIR2.1) and the epithelial $\mathrm{Na}^{+}$channel (ENaC) [41-45]. GABA and 5-HT activate afferent nerve fibers but feedback to type II cells in order to decrease further ATP secretion [15]. Glutamate is released by activated nerve fibers and tune the release of GABA and 5-HT, finally shutting down ATP secretion from type II cells [15]. Type I cells seem to have glia like function as they express several ion channels (inward rectifying $\mathrm{K}^{+}$channel [ROMK], glutamate-aspartate transporter [GLAST], $\mathrm{ENaC}$ ) which are supposed to clear ion currents $[22,23,35]$. Moreover, as $\mathrm{ENaC}$ has been identified in type I cells and this is thought to be the main receptor for the detection of low NaCl-salts, these cells may transduce salty [46]. Further channels involved in transducing salty are mucolipin 3 (TRPML3) and transient receptor potential cation channel subfamily V member 1 (TRPMV) [47]. However, their cellular localization has yet to be elucidated. In addition, the enzyme nucleoside triphosphate diphosphohydrolase-2 (NTPDase2) located on the surface of type I cells, is responsible for the degradation of ATP to adenosine diphosphate (ADP) [39]. In turn, sweet receptor expressing type II cells bind ADP by adenosine 2B receptors (A2B) which further increases sweet sensation [39]. TRPV1, transient receptor potential cation channel subfamily V member 1; PLC $\beta 2$, Phospholipase C beta 2. 
from type II cells, type III cells get depolarized in response to acids [41]. Various ion channels are implicated in the transduction of sour taste such as the epithelial $\mathrm{Na}^{+}$channel $(\mathrm{ENaC})$, the polycystic kidney disease protein 1 like 3 (PKD1L3) and PKD2L1 or the inwardly rectifying $\mathrm{K}^{+}$channel (KIR2.1) [42-45].

$\mathrm{ENaC}$ is thought to be the main receptor for the detection of $\mathrm{NaCl}$ or the taste salty [46]. Moreover, other receptors have been discussed to play a role in sensing salt such as transient receptor potential cation channel subfamily $\mathrm{V}$ member 1 (TRPV1) or TRPML3 (mucolipin 3) [47], but clear evidence for how salty is sensed is still missing.

The existence of a sixth taste quality "fat" is discussed to be located in type II cells employing glycoprotein 4 (also named cluster of differentiation 36 [CD36]), and the free fatty acid transporters GPR40 and GPR120 (GPCRs 40 and 120) [48]. These receptors recognize fatty acids rather than triglycerides derived from foods. However, fatty acids activate GPR40, GPR120, and CD36 in the same manner as substances bound to T1Rs and T2Rs by increased intracellular $\mathrm{Ca}^{2+}$ level [48-50]. There are further taste qualities discussed, namely a taste of water [51], a taste of $\mathrm{Ca}^{2+}$ salts potentially by a calcium sensing receptor (CaSR) [52] or sensations including pungency [15].

Information about taste acquired in the TBC is finally transmitted to the central nervous system via the so called "labeled line principle." This means, that for example, a single sweettaste cell is connected to a specific sweet-neuron within the geniculate, trigeminal (fungiform taste buds) or petrosal ganglion (circumvallate and filiform papillae) [53]. From there, higher order neurons follow this labeling over the brainstem to the primary gustatory cortex which seems to be located in the insula $[54,55]$.

\section{Taste bud renewal}

Although the sense of taste is already developed very early in life, the tongue is incomparably affected by external and internal stimuli leading to a need for permanent taste cell renewal throughout life. Taste cells have an average life span of 10 to 14 days [56]. This means that approximately $10 \%$ of TBC are renewed in each taste bud every day. A huge variety of factors may contribute to taste bud formation and taste cell fate during adulthood. As early as during pregnancy (10 to 13 weeks), the fetus develops differentiated and innervated taste buds suggesting functionality [56]. It has therefore been proposed that tastants present in the amniotic fluid, which are influenced by the maternal diet, may already prime early taste preferences in the developing fetus and thereby contribute to the development of obesity in later life [57]. The initial taste cells derive from the epithelial placodes and differentiate into functional taste cells after birth $[56,58]$. Wnt/ $\beta$-catenin signaling is thought to be the main initiating driver of taste placode development. Sonic hedgehog (Shh) is co-expressed and involved in placode formation and taste cell differentiation at least in fungiform papillae $[59,60]$. In contrast, circumvallate papillae formation seems to be initiated by the fibroblast growth factor (FGF) pathway [61]. Interestingly, early taste cells derived from embryonic Shh+ precursors are lost 4 months after birth and do not contribute to the life-long taste cell turn over [62]. Instead, renewal of taste cells during adulthood is sustained by a stem cell pool surrounding and/or laying within the basal niche of a taste bud [63]. Thereby, taste buds on the anterior and posterior tongue harbor distinct types of $\mathrm{K} 14+$ stem/progenitor cells (K14+/Lgr6+ and K14+/Lgr5+, respectively) $[56,63]$. The Wnt/ $\beta$-catenin pathway seems to prompt these progenitor cells to either become Shh expressing cells or nontaste keratinocytes. Shh+ cells are a post-mitotic precursor cell population (also named type IV or basal cells) entering the taste bud and developing into either type of taste cells [64]. Further downstream, specific transcription factors such as Skn1a (or POU class 2 homeobox 3 [POU2F3]) or achaetescute family BHLH transcription factor 1 (Ascl1) are thought to control which exact cell type is finally developing $[65,66]$. Shh positive basal cells signal towards the epithelial progenitor pool which express the Shh target genes patched 1 (Ptch1) and GLI family zinc finger 1 (Gli1) in order to promote cell turnover $[56,58,59]$. In addition, the transcription factor SRY-box transcription factor 2 (SOX2) has been shown to interact with Shh and regulate progenitor differentiation [67]. GLI family zinc finger 3 (Gli3), another target of Shh, is as highly expressed in Lgr5+ stem cells and contribute to their proliferation. Gli3 increases the number of Tas $1 r 3$ expressing cells indicating that cell fate decisions already take place in progenitor cells rather than only in mature type IV basal cells [68]. Collectively, specific factors trigger a proper taste cell formation and differentiation at all stages and contribute to cell fate decisions. The level of $\beta$-catenin is thought to mediate type IV cell formation and differentiation into type I, II, or III cells $[62,69]$.

The complex taste bud structures and distinct differentiation patterns may be relevant for taste (and food) preferences, eating habits and calorie consumption. Together with this important function in the regulation of food intake, the rapid TBC 
turn-over suggest their manipulation as a novel strategy in the prevention and treatment of obesity. Indeed, the loss of taste is often seen in relation to weight loss due to decreased appetite $[70,71]$. Therefore, the following sections summarize current knowledge on the sense of taste in relation to obesity and how obesity may affect adult taste buds.

\section{THE ALTERED SENSE OF TASTE IN OBESITY}

\section{Association of taste perception with body weight}

Over the past decade, the association between body mass index (BMI) and taste perception has been studied extensively with heterogeneous results. It has been repeatedly reported that increased BMI is associated with reduced perceived intensity of different taste qualities and weakened sense of taste $[4,6,72,73]$. For example, an increasing salty taste threshold (reduced salty sensitivity) was reported to be associated with higher BMI [6]. Other studies reported that adults with obesity perceive sweet and salty taste as less intensive [72] or that women with obesity have an increased mono-sodium-glutamate detection threshold (less sensitive) [73]. However, in the latter study no difference was detected between obese and normal weight women regarding sucrose threshold [73]. Contrasting these data, Hardikar et al. [4] observed a lower sucrose and sodium chloride threshold in obese compared to lean participants and concluded that obese individuals show a higher sensitivity for sweet and salty taste. Further evidence connecting taste sensitivity with obesity is derived from weight loss studies investigating changes in taste after bariatric surgery in rodents and humans. In rodents, preferential behavior is commonly used as a proxy for taste [74]. It is assumed that brief access exposure (10 to 20 seconds) better reflects sensory response to stimuli minimizing the impact of possible post-ingestive effects of direct gut-brain interaction [74]. Numerous studies found a decrease in (high concentrated) sweet taste preference after Roux-en-Y gastric bypass (RYGB) $[7,75,76]$, while no change was observed in response to other stimuli (salt, sour, bitter) [75]. An observed decreased preference for highest concentration of sucrose, but not for the lowest concentration of sucrose was interpreted as postsurgical lower sensitivity to sucrose compared to sham treated controls [7]. Moreover, rats exhibited a strong and persistent aversion to sweet tasting solutions after jejuno-ileal bypass compared to sham-operated rats. This effect could be attenuated by pre-surgery exposure to sucrose [77]. Importantly, observed sweet aversion diminished after reversal of the surgical procedure which was interpreted as an inducible change in taste perception. RYGB and vertical sleeve gastrectomy led to a similar high-sucrose aversion suggesting that sweet taste alterations are not regulated by alterations of the upper gastrointestinal tract [78]. However, opposite effects of RYGB on appetite and responsiveness to sucrose have also been reported $[79,80]$. Perceived changes in taste after bariatric surgery have also been investigated in humans, using subjective questionnaires as well as more objective controlled and standardized taste studies. Most studies report a perceived increase in sweet taste postsurgically, while some also found patients reporting an increased sensitivity to other taste qualities including salt, sour and bitter taste [81]. Increased sensitivity to sweet, sour and salty taste in some participants was reported after RYGB as well as vertical sleeve gastrectomy, although these appear to be more common in RYGB $[82,83]$. Beyond that, multiple studies demonstrate an association between the amount of weight loss and taste changes outlined above and even conclude that taste changes post-surgically may be exacerbated by weight loss suggesting a causal relationship between weight and taste perception $[83,84]$. Studies employing standardized measures to detect taste threshold largely support a post-surgical increase in sweet taste sensitivity, hence a reduced threshold for sweet taste [85-87]. Such taste desensitization may subsequently contribute to reduced intake of sweet and energy dense foods. Data reporting lower sweet taste sensitivity after bariatric surgery further suggest large intra-individual differences how weight loss and the bariatric surgery intervention may affect taste and food preferences [5,73]. Similar to the observations for sweet taste, a number of studies point towards a decreased threshold for bitter taste $[86,88]$ while others were not able to demonstrate any change of this taste quality upon weight loss [85]. Few studies reported a decreased threshold for sour taste $[87,88]$, increased sensitivity to umami taste [87], increased sensitivity to salty taste [87] and a decrease in fat taste sensitivity [89]. In line with the aforementioned, sweet taste threshold was shown to decrease (increasing sensitivity) with gradual weight loss in the context of a conservative weight loss program in obese women [90].

Taken together, associations between body weight regulation and changes in taste seem to exist and may underlie the heterogeneous response to weight loss interventions. However, it cannot be ruled out, that other factors than weight loss per se, such as reward value and gut-brain-interaction, drive the ob- 
served changes in taste perception. Beyond that, the nature of these described changes in taste perception as well as their association with food intake remains somewhat ambiguous. Although most studies point towards reduced taste sensitivity in obesity, which however is reversible with weight loss, some studies report opposing results $[4,6,72,73]$. It appears that changes in taste perception effect food selection and food intake [89]. In this sense it is interesting to mention that people with obesity often exhibit an eating behavior characterized by bigger meal sizes, increased snacking behavior and score higher on disinhibition as well as restraint scores which comprise major factors of eating behavior [91,92]. Interestingly, several studies focusing on the genetic background of obesity, eating behavior and food preferences identified genes which play a role in taste sensation. Therefore, the following section will briefly highlight what is known about genetics of eating behavior and food preferences in the context of taste sensation.

\section{Genetics and gene-environment interaction of food preferences and eating behavior in obesity}

In twin studies, the heritability for liking/disliking as well as the preference for a certain food over others has been reported in both, children and adolescents [93]. For instance, mothers of 4 to 5 -year-old twins were given a food-questionnaire of 95 foods which were finally grouped into four groups of vegetables, fruits, desserts and meat and fish. For these food groups, lowest heritability estimates were observed for desserts (0.20), moderate for vegetables $(0.37)$ and fruits $(0.51)$ and highest for meat and fish (0.78) [94]. Another study shows that genetic effects on the liking of foods in children may be more related to foods with lower nutrient density such as vegetables (54\%), fruits (53\%), or proteins (48\%) than for snacks (29\%), starches (32\%), or diary (27\%). Interestingly, the opposite was found for environmental factors which seem to have a greater effect on liking of energy dense foods (snacks $60 \%$, starches $57 \%$, and diary 54\%) [95]. One study showed high genetic heritability scores for the liking of a sucrose solution with $41 \%$ [96]. In addition, the frequency of consumption for high caloric sweets (for example, ice cream, sweets, sweet pastry, chocolate) as well as craving for sweets display high heritability scores (40\% and $31 \%$, respectively) suggesting that especially the preference for sweets is strongly genetically determined [96]. This may not be surprising as it ensures sufficient nutrient load and therefore represent an evolutionary survival advantage. Mechanistically, genetic variability of food preferences may be explained by dif- ferences in taste perception. Indeed, several studies show genetic variations, such as single nucleotide polymorphisms (SNPs) to be related to the sensation of taste or smell [97-99].

For example, SNPs within $T 1 R 1$ and $T 1 R 3$, which encode for sweet and umami receptors, have been associated with the loss of monosodium glutamate taste [100]. Most prominently, a common haplotype of the TAS2R38 is critical for the sensitivity to taste 6-n-propylthiouracil (PROP), a component for the taste of bitterness. In own studies, we could show that subjects carrying the PROP-sensitive haplotype consume less coffee and cigarettes compared to those with a different genotype [101]. Women carrying the PROP-insensitive haplotype display higher BMI and waist circumference and have been categorized by a lower restraint level [102]. In another cohort, this "non-taster haplotype" has been associated with higher disinhibition scores in women [99]. Beside these studies connecting sensitivity for tasting bitter components to eating behavior, further evidence shows specific food preferences being related to the genotype of several bitter taste receptors [103]. Interestingly, the sensation of caffeine bitterness was directly associated with messenger ribonucleic acid (mRNA) levels of several T2Rs in human taste papillae and caffeine intake in humans [104]. Therefore, gene-environment interactions seem to be an important mediator for food preference, consumption and caloric intake. Food preferences are mediated very early in life by diverse nutrients challenging the taste system [105]. CD36, a membrane transporter is an important gustatory lipid sensor which also facilitates digestion and further feeds back satiety to the brain [49]. Importantly, a SNP within CD36 is associated with the preferential consumption of oily and lipid-rich foods along with changes in gene expression level of CD36 [49]. Despite CD36, also GPR120 has been identified as lipid receptor in circumvallate taste papillae [48]. Martin and colleagues showed that mRNA expression of CD36, but not GPR120, is directly mediated by dietary fat intake and translated into spontaneous fat preference [48]. Another study could show that linoleic acid induced intracellular $\mathrm{Ca}^{2+}$ level of $\mathrm{TBC}$ by activating CD36 and GPR120 whereby the latter was only activated by high concentrations of this fatty acid [106]. Moreover, this activation seems to feedback resulting in downregulation of CD36 and upregulation of GPR120. Indeed, TBC from obese mice showed lower $\mathrm{Ca}^{2+}$ response to fatty acids [106]. Numerous other SNPs within taste receptor genes have been correlated to taste perception and food preferences and are summarized by Dioszegi et al. [103]. Collectively, these studies 
demonstrate that nutrients seem to partially drive the transcriptional machinery in taste cells with consequences on food intake. In addition, epigenetic mechanisms may mediate interactions between genetic variations and taste receptor expression. However, mechanistic studies on how genetic variants interact with environmental factors and food intake are scarce.

Despite SNPs in genes functionally related to taste buds, also genetic variations in other genes have been shown to affect the taste perception and are likewise correlated with parameters of obesity. This includes genes which have long been known as obesity candidate markers identified by genome wide association studies (GWASs) including fat mass and obesity (FTO) associated gene or brain derived neurotrophic factor $(B D N F)$ gene. For instance, the variant rs9939609 in FTO is related to dietary fat intake and variants in $B D N F$ are related to increased BMI [107-109]. Interestingly, BDNF is also a very important factor in taste bud maintenance as it is crucial to connect new taste cells with afferent nerve fibers [110]. Thereby, BDNF was shown to derive directly from taste cells rather than from the circulation [110]. In this context, it is interesting that variants in $B D N F$ have been linked to altered eating behavior and dietary intake $[111,112]$. Furthermore, the common missense variant rs6265 previously associated with obesity, was also found in a GWAS for habitual coffee consumption, suggesting a relevance in taste perception [113]. Genetic variations in semaphorin 3 (SEMA3) are associated with obesity as this guidance molecule is relevant in building hypothalamic melanocortin circuits being important for energy homeostasis [114]. In taste cells, SEMA3 is expressed in newly generated bitter taste cells and crucial for mediating a labeled-line connection to appropriate afferent bitter neurons [54]. These findings highlight the importance of oral taste tissue in explaining parts of the missing heritability of obesity. Genetic variations within FGF21 gene, a hormone primarily secreted by the liver, and its co-receptor $\beta$-klotho (KLB) are associated with food intake and alcohol consumption $[115,116]$. Moreover, FGF21 serum concentrations are strongly mediating effects on the consumption of sugar and ethanol $[116,117]$. Mice with high Fgf21 levels display reduced sugar intake when given the free choice between a regular diet and a diet enriched in sucrose compared to those with lower circulating Fgf21 [116]. These data suggest that already the taste of these diets at the level of lingual papillae might be influenced by serum FGF21 level. Indeed, several studies point out this kind of scenario where homeostatic modulators such as leptin, ghrelin or tumor necrosis factor $\alpha$
(TNF- $\alpha$ ) affect the taste sensation by directly targeting the taste tissue $[10,118,119]$. Therefore, the following paragraph attempts to integrate findings regarding hormonal/inflammatory and epigenetic factors influencing taste bud homeostasis and how obesity-specific changes may impact food selection, further pointing out possible associations with eating behavior.

\section{HOW DOES OBESITY AFFECT TASTE BUD PHYSIOLOGY}

Obesity is linked to alterations in taste sensitivity accompanied by changes in food intake. In addition to genetic factors, nutrients such as long chain fatty acids (LCFAs) [120] or caffeine [104], have been related to the mRNA expression of taste receptor genes. Moreover, hormones, cytokines and their receptors have been found to be involved in mediating taste signaling in taste cells or being relevant for the early cephalic phase response [121]. Here we will focus on integrating this knowledge to understand mechanisms in taste bud biology, regulation of taste perception and eating behavior under obese conditions and point out the effect of metabolic disturbances on taste bud biology.

\section{Hormonal modulation of the sense of taste in obesity}

Hormones can modulate the sense of taste. Strongest support for this notion has been obtained for the adipokine leptin. Leptin acts via binding to its receptor obese receptor (Ob-R) in type II TBC and interferes with local $\mathrm{K}_{\text {ATP }}$ channels $[10,122]$. The activation of $K_{\text {ATP }}$ channel results in reduced sweet response signaling to the afferent nerve fiber in the taste cell and dampens sweet perception [10]. Circadian variations in leptin concentrations are thereby overlay with variations for the sense of sweet [123]. Subjects needed higher concentrations of sucrose and saccharin when they were tested in the evening, when leptin levels peak, compared to the morning, when leptin levels decrease [123]. This diurnal variation was only evident for sweet taste and was not observed in thresholds for other taste stimuli (salty, bitter, sour). Moreover, a phase shift of the diurnal variation of leptin was performed by varying the number of meals leading to significant time-dependent changes in leptin levels which was associated with a parallel phase shift in sweet taste threshold [123]. Circulating leptin levels directly correlate with BMI [124]. As leptin dampens sweet taste sensitivity, it may account for an increased sweet taste threshold (decreased taste sensitivity) often observed in people with 
obesity [125-127]. On the other hand, increased sensitivity to sweet taste in obesity has also been found [128]. This raises the question whether leptin resistance may be of relevance in TBC regulation. In neurons signaling hunger and satiety, leptin resistance can occur as a consequence of obesity [129].

It is of note, that taste receptors have been found in the brain and play a fundamental role in regulating energy metabolism [130]. Highest expression levels have been demonstrated for $T 1 R 3, T 1 R 2$, T2R116. More interestingly, a decreased expression in obese $o b / o b$ mice and diet induced obese mice compared to a lean control group as well as significant changes after fasting has been reported for these factors. Moreover, leptin but also glucose had an effect on gene expression level of sweet taste receptors in murine hypothalamic neuron derived cells. These results indicate that taste receptors in the brain are involved in recognizing and sensing energy status and might be implicated in the control of energy homeostasis. It was further concluded that these extra-oral taste receptors may contribute to obesity and are modulated by endocrine factors [130].

More recently, adiponectin, has been supposed to be relevant in TBC which express all types of adiponectin receptors [131]. Although adiponectin knock-out mice show no differences in licking behavior by presenting a lipid emulsion, overexpression of salivary adiponectin in these mice resulted in increased responses [131]. This suggests that local adiponectin secretion is more relevant than systemic levels. Local adiponectin might derive from the salivary glands [121]. However, obese people often show elevated tongue fat which, might be a local source of adipokines affecting taste signaling [132].

However, TBC themselves have an endocrine function. Like it is known in extra-oral tissues, taste receptors can be understood as a sort of sensor for environmental factors and are involved in regulating hormone production or secretion. For example, the thyroid hormones triiodothyronine and thyroxine are released through thyroid stimulating hormone dependent $\mathrm{Ca}^{2+}$ signaling [133]. This was influenced by bitter compounds which are recognized by Tas2Rs in the thyroid gland [133]. Tas1Rs in $\beta$-cells are implicated in insulin secretion and therefore also mediating the homeostatic response to food intake. In entero-endocrine cells they regulate the release of glucagon like peptide-1 (GLP-1). Therefore, hormonal influence on taste cells may regulate taste signaling, but taste receptors seem to regulate local hormone release which indicates a fine-tuning mechanism for dietary feedback.

In mouse taste buds, GLP-1 enhances the response to su- crose and reduces the taste of sour [134]. Moreover, GLP-1 is released into the blood in response to lingual sugar supply during the cephalic phase response [135]. The release of GLP-1 from taste cells was also shown to be mediated by the binding of LCFAs to the lipid receptor GPR120 which is a mechanism for the secretion of GLP-1 in L-cells [134]. On the other hand, LCFAs are known to downregulate mRNA level of CD36 in taste cells; however, GLP-1 secretion is independent of this receptor [20]. Overall, GLP-1 signaling in TBC does not only affect taste sensation, but triggers the activity of this hormone during the cephalic phase and therefore mediates satiety signals.

Ghrelin, an appetite stimulating hormone derived from the stomach, has been found to be expressed in all types of TBC together with its receptor growth hormone secretagogue receptor (GSHR) [119] and the ghrelin O-acetyltransferase (GOAT) necessary for post-transcriptionally active ghrelin. Specific knock-out of these components in mice resulted in altered responses to salty and sour food stimuli $[119,136]$. Moreover, GOAT knock-out animals exhibit lower consumption of sweet solutions (sucrose and maltodextrin), reduced weight gain and improved glucose and insulin homeostasis [136]. Hence, the acetylation of ghrelin in taste cells might also relate to sweet sensation. At this point, it is interesting to mention that also type 2 diabetes mellitus has been related to dysgeusia and altered taste thresholds [137].

It may therefore not be surprising that important modulators of the glucose homeostasis, including glucagon and insulin, have been proven to be functionally relevant in TBC. Briefly, glucagon together with its receptor is expressed in TBC with highest abundance in T1R3 cells [138]. Not surprisingly, the authors found that glucagon increases the response to sweet stimuli in mice [138]. Insulin mRNA has been found in type II and III cells, and insulin secretion from taste cells has now been confirmed [139]. Like in the gut, insulin is thought to upregulate the expression of $\mathrm{ENaC}$ receptors in taste cells. Indeed, lingual administration of insulin increases the response to salty foods. [140]. Recently, Takai et al. [141] treated taste bud organoids in vitro with insulin which resulted in a dose-dependent downregulation of several TBC genes. Moreover, they found a loss of taste cell number in these organoids related to the mechanistic target of rapamycin pathway suggesting that insulin is relevant for taste cell proliferation. With respect to the fact that obesity is linked to the development of insulin resistance and type 2 diabetes mellitus, alterations in gustatory 
taste perception seems to be a consequence of metabolic disturbances caused by extreme overweight. Due to the high flexible nature of taste cell turnover in adulthood, especially nutritional and hormonal mediators, might be used to alter food preferences and eating behavior by directly targeting the taste cells rather than whole body metabolism.

The relevance of further hormones and signaling peptides involved in energy homeostasis in taste cells has been elegantly summarized by recent reviews $[18,20,121,142]$. In brief, endocannabinoids, oxytocin, neuropeptide Y (NPY), peptide YY (PYY), cholecystokinin (CCK), vasoactive intestinal peptide (VIP), and galanin may play a role in TBC regulation (Table 1) $[10,20$, 75,119,121,131,134,138-141,143-164].

\section{Consequences of inflammation on taste buds}

Extra-oral expression of taste receptors are implicated in innate immunity, inflammatory and autoimmune diseases are associated with altered taste perception, highlighting the potential relevance of taste cell-immune system-crosstalk [142, 165]. For example, intranasal taste receptors as well as those found in the respiratory tract, urethra and intestine have been shown to be protective against pathogens [142].

Accumulating evidence also identifies $\mathrm{TBC}$ on the tongue as a direct target for inflammatory agents and demonstrates an effect of acute inflammation on taste bud renewal and life span as well as structural integrity [118,166-169]. Feng et al. [168] demonstrated that TBC express the TNF receptors TNFR1 and TNFR2 and that the level of TNF in taste cells can be induced by inflammatory stimuli. Beyond that, behavioral tests showed that TNF-deficient mice are significantly less sensitive to the bitter compound quinine while their responses to sweet, uma$\mathrm{mi}$, salty, and sour components remained comparable to those of wild-type mice [118]. A potential underlying mechanism was described by Cohn et al. [169] (2010) who demonstrated that acute inflammation following intraperitoneal lipopolysaccharide injection inhibited proliferation of taste progenitor cells as indicated by reduced expression of Ki67 (antigen Ki67), a cell proliferation marker, resulting in a decreased number of new taste cells. Beyond that a shorter average life span of taste buds became evident. In a different study, toll-like receptors (TLRs) and type I and II interferon (IFN) receptors as well as their downstream signaling components were identified in taste tissue [166] The IFN signaling pathway was activated by administration of TLR ligands (lipopolysaccharide and double-stranded RNA polyinosinic:polycytidylic acid) and upreg- ulates the expression of IFN-inducible genes in taste buds. Moreover, systemic administration of IFNs increased apoptosis of TBC in mice [166]. From these results, a potential effect of inflammation on TBC turnover was postulated. However, obesity comprises a state of low-grade systemic inflammation $[170,171]$. More recently an implication of low grade inflammation in taste bud homeostasis in obesity has been shown. Kaufman et al. [9] (2018) demonstrated, that taste bud renewal is affected by a specific rather than overall immune response in taste epithelium which was linked to obesity. Mice fed a high fat diet showed an increased expression of TNF- $\alpha$ in taste epithelium compared to lean controls [9]. Morphologically, significant reduced taste bud abundance was observed in obese mice while no differences in size or a change in balance between type I, II, and III cells was observed. TNF- $\alpha$ knockout mice were protected against these effects. Obesity-resistant transgenic mice did neither show an increased TNF- $\alpha$ expression nor changes in markers of taste bud renewal [9]. Taken together, these results strongly suggest, that low grade inflammation and TNF- $\alpha$ affect taste bud homeostasis and renewal.

\section{Taste bud renewal in obesity}

Obesity seems to interfere with taste bud renewal through different mechanisms. Shh plays a crucial role in taste bud development during embryogenesis but also in TBC renewal throughout life. A study from 2019 shows a differential genome wide gene expression pattern of human fungiform taste buds between lean and obese which includes Shh [3]. How obesity might affect this differential gene expression pattern was not elucidated. However, effects on the transcriptional machinery in taste cells by nutrients, hormones or inflammatory factors via potential epigenetic mechanisms might be of high relevance in taste cell turnover during obesity. Indeed, some studies support epigenetic regulation of key genes involved in taste cell turnover. Just recently, Bar and colleagues found, the polycomp repressive complex 1 (PRC1), a chromatin remodeling complex, to prevent ectopic Shh expression in non-taste lingual epithelium in the developing tongue [172]. Moreover, enrichment analyses of genes being downregulated in Prc1 null mice revealed pathways such as epithelial development and cell differentiation as well as tissue development pathways [172]. Nevertheless, this mechanism has not been shown in adult taste tissue. To date, it can only be hypothesized that DNA methylation changes of key genes such as Shh may be a relevant mechanism to control renewal, fate decision and 


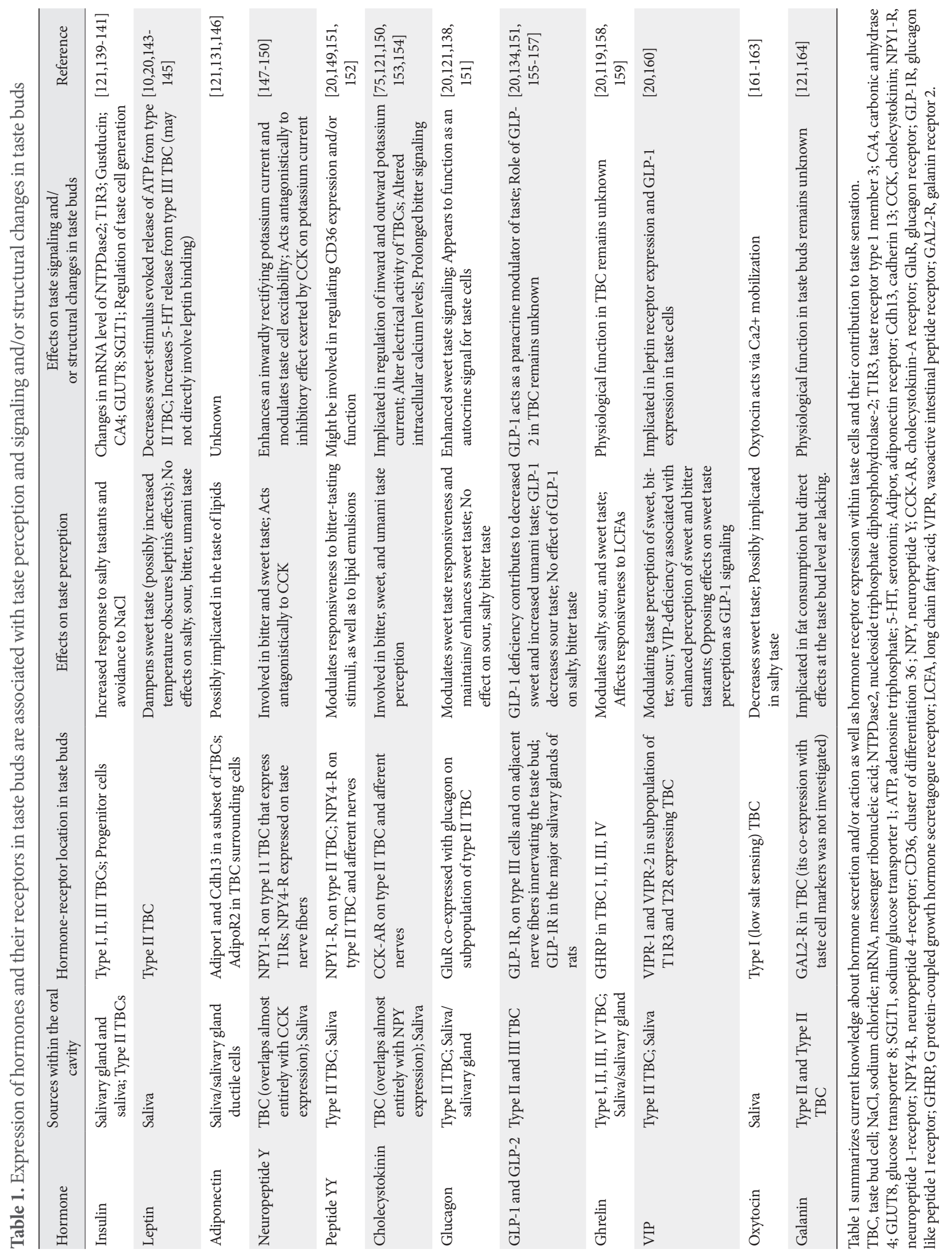


abundancy of taste cells and receptors. In extra-oral tissues such as brain and liver, it was demonstrated that DNA methylation is involved in the regulation of Shh expression [173]. Interestingly, leptin has been linked with $S h h$ gene regulation in extra-oral tissues [174] and moreover, leptin was shown to cause a downregulation of extra-oral $t 1 r 2$ and $t 1 r 3$ expression in the brain of mice [130]. Another study demonstrated global DNA methylation changes in tongue carcinoma while common tongue cancer therapies (accompanied by taste aversion and dysgeusia), target Shh $[175,176]$. Although this is highly speculative at the moment, future studies may focus on molecular mechanism of the observed gene expression differences in taste cells during obesity.

\section{CONCLUDING REMARKS AND FUTURE DIRECTIONS}

Obesity prevalence is increasing worldwide and connected to an overconsumption of high caloric and palatable food which is constantly available. The food industry is pushing this vicious circle by constantly fueling the market with tasty foods rich in sugar, fat and salt and pushing addictive like eating behaviors with consequences on whole body metabolism. Indeed, the sense of taste is closely linked to the reward driven hedonic eating and therefore strongly connected to food preferences and consequent food intake. Numerous studies have linked BMI to alterations in eating habits, unhealthy food choices and even reduced taste sensitivity such as for sweets [87]. Moreover, the obese state is linked to various metabolic disruptions including elevation in blood glucose level which may result in insulin resistance or alterations in adipokine and cytokine level leading to a systemic low grade inflammation $[1,171]$. The taste tissue on the tongue has now been shown to be affected by these challenges. A reduction in the number of taste buds was related to inflammatory processes during obesity [9], a different gene expression pattern of papillae fungiformis was shown in lean versus subjects with obesity [3] and several hormones and/or their cognate receptors are found in taste cells with a role in mediating taste sensation. As the sense of taste on the level of taste buds is a highly dynamic process and influenced by dietary and metabolic factors, this raises the question about how this knowledge can be translated into future therapeutic approaches in the treatment or prevention of obesity. However, the exact underlying molecular mechanisms linking obesity to taste cell turnover need to be understood better. For instance, what is the molecular driver of observed gene expression differences in taste cells of lean versus obese individuals? Are epigenetic mechanisms such as DNA methylation involved or are primarily post-translational modifications the reason for changes in mRNA and protein level translating into altered cell signaling? And to which extent could a specific diet prime the fate and function of newly developing taste cells during adulthood? Could targeting of TBCs by e.g., overriding sweet taste be used as a strategy for the prevention and/or treatment of obesity? The association between obesity and altered sense of taste certainly requires further research, but might be a promising target for the modulation of food preferences and overeating.

\section{CONFLICTS OF INTEREST}

No potential conflict of interest relevant to this article was reported.

\section{ORCID}

Kerstin Rohde https://orcid.org/0000-0001-5316-6870

Matthias Blüher https://orcid.org/0000-0003-0208-2065

\section{ACKNOWLEDGMENTS}

None

\section{REFERENCES}

1. Blüher M. Obesity: global epidemiology and pathogenesis. Nat Rev Endocrinol 2019;15:288-98.

2. Rossi MA, Stuber GD. Overlapping brain circuits for homeostatic and hedonic feeding. Cell Metab 2018;27:42-56.

3. Archer N, Shaw J, Cochet-Broch M, Bunch R, Poelman A, Barendse W, Duesing K. Obesity is associated with altered gene expression in human tastebuds. Int J Obes (Lond) 2019; 43:1475-84.

4. Hardikar S, Hochenberger R, Villringer A, Ohla K. Higher sensitivity to sweet and salty taste in obese compared to lean individuals. Appetite 2017;111:158-65.

5. Kittrell H, Graber W, Mariani E, Czaja K, Hajnal A, Di Lorenzo PM. Taste and odor preferences following Roux-en-Y surgery in humans. PLoS One 2018;13:e0199508.

6. Skrandies W, Zschieschang R. Olfactory and gustatory func- 
tions and its relation to body weight. Physiol Behav 2015;142: $1-4$.

7. Tichansky DS, Glatt AR, Madan AK, Harper J, Tokita K, Boughter JD. Decrease in sweet taste in rats after gastric bypass surgery. Surg Endosc 2011;25:1176-81.

8. Liu D, Archer N, Duesing K, Hannan G, Keast R. Mechanism of fat taste perception: association with diet and obesity. Prog Lipid Res 2016;63:41-9.

9. Kaufman A, Choo E, Koh A, Dando R. Inflammation arising from obesity reduces taste bud abundance and inhibits renewal. PLoS Biol 2018;16:e2001959.

10. Kubasova N, Burdakov D, Domingos AI. Sweet and low on leptin: hormonal regulation of sweet taste buds. Diabetes 2015;64:3651-2.

11. Meredith TL, Corcoran A, Roper SD. Leptin's effect on taste bud calcium responses and transmitter secretion. Chem Senses 2015;40:217-22.

12. Garcia-Bailo B, Toguri C, Eny KM, El-Sohemy A. Genetic variation in taste and its influence on food selection. OMICS 2009;13:69-80.

13. Chandrashekar J, Hoon MA, Ryba NJ, Zuker CS. The receptors and cells for mammalian taste. Nature 2006;444:288-94.

14. Besnard P, Passilly-Degrace P, Khan NA. Taste of fat: a sixth taste modality? Physiol Rev 2016;96:151-76.

15. Roper SD, Chaudhari N. Taste buds: cells, signals and synapses. Nat Rev Neurosci 2017;18:485-97.

16. Travers SP, Nicklas K. Taste bud distribution in the rat pharynx and larynx. Anat Rec 1990;227:373-9.

17. Nilsson B. The occurrence of taste buds in the palate of human adults as evidenced by light microscopy. Acta Odontol Scand 1979;37:253-8.

18. Loper HB, La Sala M, Dotson C, Steinle N. Taste perception, associated hormonal modulation, and nutrient intake. Nutr Rev 2015;73:83-91.

19. Gravina SA, Yep GL, Khan M. Human biology of taste. Ann Saudi Med 2013;33:217-22.

20. Calvo SS, Egan JM. The endocrinology of taste receptors. Nat Rev Endocrinol 2015;11:213-27.

21. Murray RG. Cellular relations in mouse circumvallate taste buds. Microsc Res Tech 1993;26:209-24.

22. Vandenbeuch A, Anderson CB, Parnes J, Enjyoji K, Robson SC, Finger TE, Kinnamon SC. Role of the ectonucleotidase NTPDase2 in taste bud function. Proc Natl Acad Sci U S A 2013;110:14789-94.

23. Lawton DM, Furness DN, Lindemann B, Hackney CM. Lo- calization of the glutamate-aspartate transporter, GLAST, in rat taste buds. Eur J Neurosci 2000;12:3163-71.

24. Dvoryanchikov G, Sinclair MS, Perea-Martinez I, Wang T, Chaudhari N. Inward rectifier channel, ROMK, is localized to the apical tips of glial-like cells in mouse taste buds. J Comp Neurol 2009;517:1-14.

25. Tomchik SM, Berg S, Kim JW, Chaudhari N, Roper SD. Breadth of tuning and taste coding in mammalian taste buds. Version 2. J Neurosci 2007;27:10840-8.

26. Ozeck M, Brust P, Xu H, Servant G. Receptors for bitter, sweet and umami taste couple to inhibitory $\mathrm{G}$ protein signaling pathways. Eur J Pharmacol 2004;489:139-49.

27. Toyono T, Seta Y, Kataoka S, Oda M, Toyoshima K. Differential expression of the glucose transporters in mouse gustatory papillae. Cell Tissue Res 2011;345:243-52.

28. Yee KK, Sukumaran SK, Kotha R, Gilbertson TA, Margolskee RF. Glucose transporters and ATP-gated K+ (KATP) metabolic sensors are present in type 1 taste receptor 3 (T1r3)-expressing taste cells. Proc Natl Acad Sci U S A 2011;108:5431-6.

29. Nelson G, Chandrashekar J, Hoon MA, Feng L, Zhao G, Ryba NJ, Zuker CS. An amino-acid taste receptor. Nature 2002;416: 199-202.

30. Zhao GQ, Zhang Y, Hoon MA, Chandrashekar J, Erlenbach I, Ryba NJ, Zuker CS. The receptors for mammalian sweet and umami taste. Cell 2003;115:255-66.

31. Chaudhari N, Landin AM, Roper SD. A metabotropic glutamate receptor variant functions as a taste receptor. Nat Neurosci 2000;3:113-9.

32. Behrens M, Foerster S, Staehler F, Raguse JD, Meyerhof W. Gustatory expression pattern of the human TAS2R bitter receptor gene family reveals a heterogenous population of bitter responsive taste receptor cells. J Neurosci 2007;27:12630-40.

33. Adler E, Hoon MA, Mueller KL, Chandrashekar J, Ryba NJ, Zuker CS. A novel family of mammalian taste receptors. Cell 2000;100:693-702.

34. Liu D, Liman ER. Intracellular Ca2+ and the phospholipid PIP2 regulate the taste transduction ion channel TRPM5. Proc Natl Acad Sci U S A 2003;100:15160-5.

35. Taruno A, Vingtdeux V, Ohmoto M, Ma Z, Dvoryanchikov G, Li A, Adrien L, Zhao H, Leung S, Abernethy M, Koppel J, Davies P, Civan MM, Chaudhari N, Matsumoto I, Hellekant G, Tordoff MG, Marambaud P, Foskett JK. CALHM1 ion channel mediates purinergic neurotransmission of sweet, bitter and umami tastes. Nature 2013;495:223-6.

36. Kinnamon SC, Finger TE. A taste for ATP: neurotransmission 
in taste buds. Front Cell Neurosci 2013;7:264.

37. Huang YJ, Maruyama Y, Dvoryanchikov G, Pereira E, Chaudhari N, Roper SD. The role of pannexin 1 hemichannels in ATP release and cell-cell communication in mouse taste buds. Proc Natl Acad Sci U S A 2007;104:6436-41.

38. Dando R, Roper SD. Acetylcholine is released from taste cells, enhancing taste signalling. J Physiol 2012;590:3009-17.

39. Dando R, Dvoryanchikov G, Pereira E, Chaudhari N, Roper $\mathrm{SD}$. Adenosine enhances sweet taste through $\mathrm{A} 2 \mathrm{~B}$ receptors in the taste bud. Version 2. J Neurosci 2012;32:322-30.

40. Wilson CE, Finger TE, Kinnamon SC. Type III cells in anterior taste fields are more immunohistochemically diverse than those of posterior taste fields in mice. Chem Senses 2017;42: 759-67.

41. Lyall V, Alam RI, Phan DQ, Ereso GL, Phan TH, Malik SA, Montrose MH, Chu S, Heck GL, Feldman GM, DeSimone JA. Decrease in rat taste receptor cell intracellular $\mathrm{pH}$ is the proximate stimulus in sour taste transduction. Am J Physiol Cell Physiol 2001;281:C1005-13.

42. Ye W, Chang RB, Bushman JD, Tu YH, Mulhall EM, Wilson CE, Cooper AJ, Chick WS, Hill-Eubanks DC, Nelson MT, Kinnamon SC, Liman ER. The K+ channel KIR2.1 functions in tandem with proton influx to mediate sour taste transduction. Proc Natl Acad Sci U S A 2016;113:E229-38.

43. Huang AL, Chen X, Hoon MA, Chandrashekar J, Guo W, Trankner D, Ryba NJ, Zuker CS. The cells and logic for mammalian sour taste detection. Nature 2006;442:934-8.

44. Huque T, Cowart BJ, Dankulich-Nagrudny L, Pribitkin EA, Bayley DL, Spielman AI, Feldman RS, Mackler SA, Brand JG. Sour ageusia in two individuals implicates ion channels of the ASIC and PKD families in human sour taste perception at the anterior tongue. PLoS One 2009;4:e7347.

45. Gilbertson TA, Avenet P, Kinnamon SC, Roper SD. Proton currents through amiloride-sensitive $\mathrm{Na}$ channels in hamster taste cells. Role in acid transduction. J Gen Physiol 1992;100: 803-24.

46. Heck GL, Mierson S, DeSimone JA. Salt taste transduction occurs through an amiloride-sensitive sodium transport pathway. Science 1984;223:403-5.

47. Bachmanov AA, Bosak NP, Lin C, Matsumoto I, Ohmoto M, Reed DR, Nelson TM. Genetics of taste receptors. Curr Pharm Des 2014;20:2669-83.

48. Martin C, Passilly-Degrace P, Gaillard D, Merlin JF, Chevrot M, Besnard P. The lipid-sensor candidates CD36 and GPR120 are differentially regulated by dietary lipids in mouse taste buds: impact on spontaneous fat preference. PloS One 2011;6: e24014.

49. Niot I, Besnard P. Appetite control by the tongue-gut axis and evaluation of the role of CD36/SR-B2. Biochimie 2017;136:2732.

50. Laugerette F, Passilly-Degrace P, Patris B, Niot I, Febbraio M, Montmayeur JP, Besnard P. CD36 involvement in orosensory detection of dietary lipids, spontaneous fat preference, and digestive secretions. J Clin Invest 2005;115:3177-84.

51. Zocchi D, Wennemuth G, Oka Y. The cellular mechanism for water detection in the mammalian taste system. Nat Neurosci 2017;20:927-33.

52. Ohsu T, Amino Y, Nagasaki H, Yamanaka T, Takeshita S, Hatanaka T, Maruyama Y, Miyamura N, Eto Y. Involvement of the calcium-sensing receptor in human taste perception. J Biol Chem 2010;285:1016-22.

53. Mistretta CM, Kumari A. Hedgehog signaling regulates taste organs and oral sensation: distinctive roles in the epithelium, stroma, and innervation. Int J Mol Sci 2019;20:1341.

54. Lee H, Macpherson LJ, Parada CA, Zuker CS, Ryba NJP. Rewiring the taste system. Nature 2017;548:330-3.

55. Chikazoe J, Lee DH, Kriegeskorte N, Anderson AK. Distinct representations of basic taste qualities in human gustatory cortex. Nat Commun 2019;10:1048.

56. Barlow LA. Progress and renewal in gustation: new insights into taste bud development. Development 2015;142:3620-9.

57. Dyer JS, Rosenfeld CR. Metabolic imprinting by prenatal, perinatal, and postnatal overnutrition: a review. Semin Reprod Med 2011;29:266-76.

58. Barlow LA, Klein OD. Developing and regenerating a sense of taste. Curr Top Dev Biol 2015;111:401-19.

59. Liu HX, Ermilov A, Grachtchouk M, Li L, Gumucio DL, Dlugosz AA, Mistretta CM. Multiple Shh signaling centers participate in fungiform papilla and taste bud formation and maintenance. Dev Biol 2013;382:82-97.

60. Liu F, Thirumangalathu S, Gallant NM, Yang SH, Stoick-Cooper CL, Reddy ST, Andl T, Taketo MM, Dlugosz AA, Moon RT, Barlow LA, Millar SE. Wnt-beta-catenin signaling initiates taste papilla development. Nat Genet 2007;39:106-12.

61. Rothova M, Thompson H, Lickert H, Tucker AS. Lineage tracing of the endoderm during oral development. Dev Dyn 2012; 241:1183-91.

62. Thirumangalathu S, Harlow DE, Driskell AL, Krimm RF, Barlow LA. Fate mapping of mammalian embryonic taste bud progenitors. Development 2009;136:1519-28. 
63. Feng P, Huang L, Wang H. Taste bud homeostasis in health, disease, and aging. Chem Senses 2014;39:3-16.

64. Miura H, Barlow LA. Taste bud regeneration and the search for taste progenitor cells. Arch Ital Biol 2010;148:107-18.

65. Miura H, Kusakabe Y, Harada S. Cell lineage and differentiation in taste buds. Arch Histol Cytol 2006;69:209-25.

66. Matsumoto I, Ohmoto M, Narukawa M, Yoshihara Y, Abe K. Skn-1a (Pou2f3) specifies taste receptor cell lineage. Nat Neurosci 2011;14:685-7.

67. Castillo-Azofeifa D, Seidel K, Gross L, Golden EJ, Jacquez B, Klein OD, Barlow LA. SOX2 regulation by hedgehog signaling controls adult lingual epithelium homeostasis. Development 2018;145:dev164889.

68. Qin Y, Sukumaran SK, Jyotaki M, Redding K, Jiang P, Margolskee RF. Gli3 is a negative regulator of Tas1r3-expressing taste cells. PLoS Genet 2018;14:e1007058.

69. Thirumangalathu $S$, Barlow LA. $\beta$-Catenin signaling regulates temporally discrete phases of anterior taste bud development. Development 2015;142:4309-17.

70. Kershaw JC, Mattes RD. Nutrition and taste and smell dysfunction. World J Otorhinolaryngol Head Neck Surg 2018;4: 3-10.

71. Woschnagg H, Stollberger C, Finsterer J. Loss of taste is loss of weight. Lancet 2002;359:891.

72. Sartor F, Donaldson LF, Markland DA, Loveday H, Jackson MJ, Kubis HP. Taste perception and implicit attitude toward sweet related to body mass index and soft drink supplementation. Appetite 2011;57:237-46.

73. Pepino MY, Finkbeiner S, Beauchamp GK, Mennella JA. Obese women have lower monosodium glutamate taste sensitivity and prefer higher concentrations than do normalweight women. Obesity (Silver Spring) 2010;18:959-65.

74. Gaillard D, Stratford JM. Measurement of behavioral taste responses in mice: two-bottle preference, lickometer, and conditioned taste-aversion tests. Curr Protoc Mouse Biol 2016;6: 380-407.

75. Hajnal A, Kovacs P, Ahmed T, Meirelles K, Lynch CJ, Cooney RN. Gastric bypass surgery alters behavioral and neural taste functions for sweet taste in obese rats. Am J Physiol Gastrointest Liver Physiol 2010;299:G967-79.

76. Nielsen MS, Andersen INSK, Lange B, Ritz C, le Roux CW, Schmidt JB, Sjodin A, Bredie WLP. Bariatric surgery leads to short-term effects on sweet taste sensitivity and hedonic evaluation of fatty food stimuli. Obesity (Silver Spring) 2019;27: 1796-804.
77. Sclafani A, Koopmans HS. Intestinal bypass surgery produces conditioned taste aversion in rats. Int J Obes 1981;5:497-500.

78. Wilson-Perez HE, Chambers AP, Sandoval DA, Stefater MA, Woods SC, Benoit SC, Seeley RJ. The effect of vertical sleeve gastrectomy on food choice in rats. Int J Obes (Lond) 2013;37: 288-95.

79. Mathes CM. Taste- and flavor-guided behaviors following Roux-en-Y gastric bypass in rodent models. Appetite 2020; 146:104422.

80. Mathes CM, Bueter M, Smith KR, Lutz TA, le Roux CW, Spector AC. Roux-en-Y gastric bypass in rats increases sucrose taste-related motivated behavior independent of pharmacological GLP-1-receptor modulation. Am J Physiol Regul Integr Comp Physiol 2012;302:R751-67.

81. Shoar S, Naderan M, Shoar N, Modukuru VR, Mahmoodzadeh $\mathrm{H}$. Alteration pattern of taste perception after bariatric surgery: a systematic review of four taste domains. Obes Surg 2019;29:1542-50.

82. Makaronidis JM, Batterham RL. Potential mechanisms mediating sustained weight loss following roux-en-y gastric bypass and sleeve gastrectomy. Endocrinol Metab Clin North Am 2016;45:539-52.

83. Makaronidis JM, Neilson S, Cheung WH, Tymoszuk U, Pucci A, Finer N, Doyle J, Hashemi M, Elkalaawy M, Adamo M, Jenkinson A, Batterham RL. Reported appetite, taste and smell changes following Roux-en-Y gastric bypass and sleeve gastrectomy: effect of gender, type 2 diabetes and relationship to post-operative weight loss. Appetite 2016;107:93-105.

84. Van Vuuren MAJ, Strodl E, White KM, Lockie PD. Taste, enjoyment, and desire of flavors change after sleeve gastrectomyshort term results. Obes Surg 2017;27:1466-73.

85. Burge JC, Schaumburg JZ, Choban PS, DiSilvestro RA, Flancbaum L. Changes in patients' taste acuity after Roux-enY gastric bypass for clinically severe obesity. J Am Diet Assoc 1995;95:666-70.

86. Holinski F, Menenakos C, Haber G, Olze H, Ordemann J. Olfactory and gustatory function after bariatric surgery. Obes Surg 2015;25:2314-20.

87. Altun H, Hanci D, Altun H, Batman B, Serin RK, Karip AB, Akyuz U. Improved gustatory sensitivity in morbidly obese patients after laparoscopic sleeve gastrectomy. Ann Otol Rhinol Laryngol 2016;125:536-40.

88. Scruggs DM, Buffington C, Cowan GS Jr. Taste acuity of the morbidly obese before and after gastric bypass surgery. Obes Surg 1994;4:24-8. 
89. Zakeri R, Batterham RL. Potential mechanisms underlying the effect of bariatric surgery on eating behaviour. Curr Opin Endocrinol Diabetes Obes 2018;25:3-11.

90. Umabiki M, Tsuzaki K, Kotani K, Nagai N, Sano Y, Matsuoka Y, Kitaoka K, Okami Y, Sakane N, Higashi A. The improvement of sweet taste sensitivity with decrease in serum leptin levels during weight loss in obese females. Tohoku J Exp Med 2010;220:267-71.

91. Olea Lopez AL, Johnson L. Associations between restrained eating and the size and frequency of overall intake, meal, snack and drink occasions in the UK adult national diet and nutrition survey. PLoS One 2016;11:e0156320.

92. Stunkard AJ, Messick S. The three-factor eating questionnaire to measure dietary restraint, disinhibition and hunger. J Psychosom Res 1985;29:71-83.

93. Robino A, Concas MP, Catamo E, Gasparini P. A brief review of genetic approaches to the study of food preferences: current knowledge and future directions. Nutrients 2019;11:1735.

94. Breen FM, Plomin R, Wardle J. Heritability of food preferences in young children. Physiol Behav 2006;88:443-7.

95. Fildes A, van Jaarsveld CH, Llewellyn CH, Fisher A, Cooke L, Wardle J. Nature and nurture in children's food preferences. Am J Clin Nutr 2014;99:911-7.

96. Keskitalo K, Knaapila A, Kallela M, Palotie A, Wessman M, Sammalisto S, Peltonen L, Tuorila H, Perola M. Sweet taste preferences are partly genetically determined: identification of a trait locus on chromosome 16. Am J Clin Nutr 2007;86:5563.

97. Choquette AC, Bouchard L, Drapeau V, Lemieux S, Tremblay A, Bouchard C, Vohl MC, Perusse L. Association between olfactory receptor genes, eating behavior traits and adiposity: results from the Quebec Family Study. Physiol Behav 2012; 105:772-6.

98. Stafford LD, Whittle A. Obese individuals have higher preference and sensitivity to odor of chocolate. Chem Senses 2015; 40:279-84.

99. Dotson CD, Shaw HL, Mitchell BD, Munger SD, Steinle NI. Variation in the gene TAS2R38 is associated with the eating behavior disinhibition in Old Order Amish women. Appetite 2010;54:93-9.

100. Shigemura N, Shirosaki S, Ohkuri T, Sanematsu K, Islam AA, Ogiwara Y, Kawai M, Yoshida R, Ninomiya Y. Variation in umami perception and in candidate genes for the umami receptor in mice and humans. Am J Clin Nutr 2009;90:764S-9S.

101. Keller M, Liu X, Wohland T, Rohde K, Gast MT, Stumvoll M,
Kovacs P, Tonjes A, Bottcher Y. TAS2R38 and its influence on smoking behavior and glucose homeostasis in the German Sorbs. PLoS One 2013;8:e80512.

102. Tepper BJ, Koelliker Y, Zhao L, Ullrich NV, Lanzara C, d’Adamo P, Ferrara A, Ulivi S, Esposito L, Gasparini P. Variation in the bitter-taste receptor gene TAS2R38, and adiposity in a genetically isolated population in Southern Italy. Obesity (Silver Spring) 2008;16:2289-95.

103. Dioszegi J, Llanaj E, Adany R. Genetic background of taste perception, taste preferences, and its nutritional implications: a systematic review. Front Genet 2019;10:1272.

104. Lipchock SV, Spielman AI, Mennella JA, Mansfield CJ, Hwang LD, Douglas JE, Reed DR. Caffeine bitterness is related to daily caffeine intake and bitter receptor mRNA abundance in human taste tissue. Perception 2017;46:245-56.

105. Ventura AK, Worobey J. Early influences on the development of food preferences. Curr Biol 2013;23:R401-8.

106. Ozdener MH, Subramaniam S, Sundaresan S, Sery O, Hashimoto T, Asakawa Y, Besnard P, Abumrad NA, Khan NA. CD36- and GPR120-mediated $\mathrm{Ca}^{2+}$ signaling in human taste bud cells mediates differential responses to fatty acids and is altered in obese mice. Gastroenterology 2014;146:995-1005.

107. Thorleifsson G, Walters GB, Gudbjartsson DF, Steinthorsdottir V, Sulem P, Helgadottir A, Styrkarsdottir U, Gretarsdottir S, Thorlacius S, Jonsdottir I, Jonsdottir T, Olafsdottir EJ, Olafsdottir GH, Jonsson T, Jonsson F, Borch-Johnsen K, Hansen T, Andersen G, Jorgensen T, Lauritzen T, Aben KK, Verbeek AL, Roeleveld N, Kampman E, Yanek LR, Becker LC, Tryggvadottir L, Rafnar T, Becker DM, Gulcher J, Kiemeney LA, Pedersen O, Kong A, Thorsteinsdottir U, Stefansson K. Genome-wide association yields new sequence variants at seven loci that associate with measures of obesity. Nat Genet 2009;41:18-24.

108. Daya M, Pujianto DA, Witjaksono F, Priliani L, Susanto J, Lukito W, Malik SG. Obesity risk and preference for high dietary fat intake are determined by FTO rs9939609 gene polymorphism in selected Indonesian adults. Asia Pac J Clin Nutr 2019;28:183-91.

109. Merritt DC, Jamnik J, El-Sohemy A. FTO genotype, dietary protein intake, and body weight in a multiethnic population of young adults: a cross-sectional study. Genes Nutr 2018;13:4.

110. Meng L, Ohman-Gault L, Ma L, Krimm RF. Taste bud-derived $\mathrm{BDNF}$ is required to maintain normal amounts of innervation to adult taste buds. eNeuro 2015;2:ENEURO.

111. McCaffery JM, Jablonski KA, Franks PW, Delahanty LM, Aroda V, Marrero D, Hamman RF, Horton ES, Dagogo-Jack S, 
Wylie-Rosett J, Barrett-Connor E, Kitabchi A, Knowler WC, Wing RR, Florez JC; Diabetes Prevention Program Research Group. Replication of the association of BDNF and MC4R variants with dietary intake in the diabetes prevention program. Psychosom Med 2017;79:224-33.

112. Bauer F, Elbers CC, Adan RA, Loos RJ, Onland-Moret NC, Grobbee DE, van Vliet-Ostaptchouk JV, Wijmenga C, van der Schouw YT. Obesity genes identified in genome-wide association studies are associated with adiposity measures and potentially with nutrient-specific food preference. Am J Clin Nutr 2009;90:951-9.

113. Coffee and Caffeine Genetics Consortium, Cornelis MC, Byrne EM, Esko T, Nalls MA, Ganna A, Paynter N, Monda KL, Amin N, Fischer K, Renstrom F, Ngwa JS, Huikari V, Cavadino A, Nolte IM, Teumer A, Yu K, Marques-Vidal P, Rawal R, Manichaikul A, Wojczynski MK, Vink JM, Zhao JH, Burlutsky G, Lahti J, Mikkila V, Lemaitre RN, Eriksson J, Musani SK, Tanaka T, Geller F, Luan J, Hui J, Magi R, Dimitriou M, Garcia ME, Ho WK, Wright MJ, Rose LM, Magnusson PK, Pedersen NL, Couper D, Oostra BA, Hofman A, Ikram MA, Tiemeier HW, Uitterlinden AG, van Rooij FJ, Barroso I, Johansson I, Xue L, Kaakinen M, Milani L, Power C, Snieder H, Stolk RP, Baumeister SE, Biffar R, Gu F, Bastardot F, Kutalik Z, Jacobs DR Jr, Forouhi NG, Mihailov E, Lind L, Lindgren C, Michaelsson K, Morris A, Jensen M, Khaw KT, Luben RN, Wang JJ, Mannisto S, Perala MM, Kahonen M, Lehtimaki T, Viikari J, Mozaffarian D, Mukamal K, Psaty BM, Doring A, Heath AC, Montgomery GW, Dahmen N, Carithers T, Tucker KL, Ferrucci L, Boyd HA, Melbye M, Treur JL, Mellstrom D, Hottenga JJ, Prokopenko I, Tonjes A, Deloukas P, Kanoni S, Lorentzon M, Houston DK, Liu Y, Danesh J, Rasheed A, Mason MA, Zonderman AB, Franke L, Kristal BS; International Parkinson's Disease Genomics Consortium (IPDGC); North American Brain Expression Consortium (NABEC); UK Brain Expression Consortium (UKBEC), Karjalainen J, Reed DR, Westra HJ, Evans MK, Saleheen D, Harris TB, Dedoussis G, Curhan G, Stumvoll M, Beilby J, Pasquale LR, Feenstra B, Bandinelli S, Ordovas JM, Chan AT, Peters U, Ohlsson C, Gieger C, Martin NG, Waldenberger M, Siscovick DS, Raitakari O, Eriksson JG, Mitchell P, Hunter DJ, Kraft P, Rimm EB, Boomsma DI, Borecki IB, Loos RJ, Wareham NJ, Vollenweider P, Caporaso N, Grabe HJ, Neuhouser ML, Wolffenbuttel BH, Hu FB, Hypponen E, Jarvelin MR, Cupples LA, Franks PW, Ridker PM, van Duijn CM, Heiss G, Metspalu A, North KE, Ingelsson E, Nettleton JA, van Dam RM, Chasman DI. Genome-wide meta-analysis identifies six novel loci associated with habitual coffee consumption. Mol Psychiatry 2015;20:647-56.

114. van der Klaauw AA, Croizier S, Mendes de Oliveira E, Stadler LKJ, Park S, Kong Y, Banton MC, Tandon P, Hendricks AE, Keogh JM, Riley SE, Papadia S, Henning E, Bounds R, Bochukova EG, Mistry V, O’Rahilly S, Simerly RB; INTERVAL; UK10K Consortium, Minchin JEN, Barroso I, Jones EY, Bouret SG, Farooqi IS. Human semaphorin 3 variants link melanocortin circuit development and energy balance. Cell 2019; 176:729-42.

115. Soberg S, Sandholt CH, Jespersen NZ, Toft U, Madsen AL, von Holstein-Rathlou S, Grevengoed TJ, Christensen KB, Bredie WLP, Potthoff MJ, Solomon TPJ, Scheele C, Linneberg A, Jorgensen T, Pedersen O, Hansen T, Gillum MP, Grarup N. FGF21 is a sugar-induced hormone associated with sweet intake and preference in humans. Cell Metab 2017;25:1045-53.

116. von Holstein-Rathlou S, Gillum MP. Fibroblast growth factor 21: an endocrine inhibitor of sugar and alcohol appetite. J Physiol 2019;597:3539-48.

117. Frayling TM, Beaumont RN, Jones SE, Yaghootkar H, Tuke MA, Ruth KS, Casanova F, West B, Locke J, Sharp S, Ji Y, Thompson W, Harrison J, Etheridge AS, Gallins PJ, Jima D, Wright F, Zhou Y, Innocenti F, Lindgren CM, Grarup N, Murray A, Freathy RM, Weedon MN, Tyrrell J, Wood AR. A common allele in FGF21 associated with sugar intake is associated with body shape, lower total body-fat percentage, and higher blood pressure. Cell Rep 2018;23:327-36.

118. Feng P, Jyotaki M, Kim A, Chai J, Simon N, Zhou M, Bachmanov AA, Huang L, Wang H. Regulation of bitter taste responses by tumor necrosis factor. Brain Behav Immun 2015; 49:32-42.

119. Shin YK, Martin B, Kim W, White CM, Ji S, Sun Y, Smith RG, Sevigny J, Tschop MH, Maudsley S, Egan JM. Ghrelin is produced in taste cells and ghrelin receptor null mice show reduced taste responsivity to salty $(\mathrm{NaCl})$ and sour (citric acid) tastants. PLoS One 2010;5:e12729.

120. Passilly-Degrace P, Chevrot M, Bernard A, Ancel D, Martin C, Besnard P. Is the taste of fat regulated? Biochimie 2014;96:3-7.

121. Zolotukhin S. Metabolic hormones in saliva: origins and functions. Oral Dis 2013;19:219-29.

122. Shigemura N, Miura H, Kusakabe Y, Hino A, Ninomiya Y. Expression of leptin receptor (Ob-R) isoforms and signal transducers and activators of transcription (STATs) mRNAs in the mouse taste buds. Arch Histol Cytol 2003;66:253-60.

123. Nakamura Y, Sanematsu K, Ohta R, Shirosaki S, Koyano K, 
Nonaka K, Shigemura N, Ninomiya Y. Diurnal variation of human sweet taste recognition thresholds is correlated with plasma leptin levels. Diabetes 2008;57:2661-5.

124. Hamann A, Matthaei S. Regulation of energy balance by leptin. Exp Clin Endocrinol Diabetes 1996;104:293-300.

125. Bartoshuk LM, Duffy VB, Hayes JE, Moskowitz HR, Snyder DJ. Psychophysics of sweet and fat perception in obesity: problems, solutions and new perspectives. Philos Trans R Soc Lond B Biol Sci 2006;361:1137-48.

126. Sclafani A. Oral, post-oral and genetic interactions in sweet appetite. Physiol Behav 2006;89:525-30.

127. Sanematsu K, Nakamura Y, Nomura M, Shigemura N, Ninomiya Y. Diurnal variation of sweet taste recognition thresholds is absent in overweight and obese humans. Nutrients 2018;10:297.

128. Shigemura N, Ohta R, Kusakabe Y, Miura H, Hino A, Koyano K, Nakashima K, Ninomiya Y. Leptin modulates behavioral responses to sweet substances by influencing peripheral taste structures. Endocrinology 2004;145:839-47.

129. Jequier E. Leptin signaling, adiposity, and energy balance. Ann N Y Acad Sci 2002;967:379-88.

130. Herrera Moro Chao D, Argmann C, Van Eijk M, Boot RG, Ottenhoff R, Van Roomen C, Foppen E, Siljee JE, Unmehopa UA, Kalsbeek A, Aerts JM. Impact of obesity on taste receptor expression in extra-oral tissues: emphasis on hypothalamus and brainstem. Sci Rep 2016;6:29094.

131. Crosson SM, Marques A, Dib P, Dotson CD, Munger SD, Zolotukhin S. Taste receptor cells in mice express receptors for the hormone adiponectin. Chem Senses 2019;44:409-22.

132. Kim AM, Keenan BT, Jackson N, Chan EL, Staley B, Poptani H, Torigian DA, Pack AI, Schwab RJ. Tongue fat and its relationship to obstructive sleep apnea. Sleep 2014;37:1639-48.

133. Clark AA, Dotson CD, Elson AE, Voigt A, Boehm U, Meyerhof W, Steinle NI, Munger SD. TAS2R bitter taste receptors regulate thyroid function. FASEB J 2015;29:164-72.

134. Martin C, Passilly-Degrace P, Chevrot M, Ancel D, Sparks SM, Drucker DJ, Besnard P. Lipid-mediated release of GLP-1 by mouse taste buds from circumvallate papillae: putative involvement of GPR120 and impact on taste sensitivity. J Lipid Res 2012;53:2256-65.

135. Kokrashvili Z, Yee KK, Ilegems E, Iwatsuki K, Li Y, Mosinger B, Margolskee RF. Endocrine taste cells. Br J Nutr 2014;111 Suppl 1:S23-9.

136. Kouno T, Akiyama N, Fujieda K, Nanchi I, Okuda T, Iwasaki T, Oka S, Yukioka H. Reduced intake of carbohydrate prevents the development of obesity and impaired glucose metabolism in ghrelin O-acyltransferase knockout mice. Peptides 2016;86: 145-52.

137. De Carli L, Gambino R, Lubrano C, Rosato R, Bongiovanni D, Lanfranco F, Broglio F, Ghigo E, Bo S. Impaired taste sensation in type 2 diabetic patients without chronic complications: a case-control study. J Endocrinol Invest 2018;41:765-72.

138. Elson AE, Dotson CD, Egan JM, Munger SD. Glucagon signaling modulates sweet taste responsiveness. FASEB J 2010;24: 3960-9.

139. Doyle ME, Fiori JL, Gonzalez Mariscal I, Liu QR, Goodstein E, Yang H, Shin YK, Santa-Cruz Calvo S, Indig FE, Egan JM. Insulin is transcribed and translated in mammalian taste bud cells. Endocrinology 2018;159:3331-9.

140. Baquero AF, Gilbertson TA. Insulin activates epithelial sodium channel $(\mathrm{ENaC})$ via phosphoinositide 3-kinase in mammalian taste receptor cells. Am J Physiol Cell Physiol 2011; 300:C860-71.

141. Takai S, Watanabe Y, Sanematsu K, Yoshida R, Margolskee RF, Jiang P, Atsuta I, Koyano K, Ninomiya Y, Shigemura N. Effects of insulin signaling on mouse taste cell proliferation. PLoS One 2019;14:e0225190.

142. Behrens M, Meyerhof W. A role for taste receptors in (neuro) endocrinology? J Neuroendocrinol 2019;31:e12691.

143. Yoshida R, Noguchi K, Shigemura N, Jyotaki M, Takahashi I, Margolskee RF, Ninomiya Y. Leptin suppresses mouse taste cell responses to sweet compounds. Diabetes 2015;64:3751-62.

144. Rodrigues L, Espanca R, Costa AR, Antunes CM, Pomar C, Capela-Silva F, Pinheiro CC, Amado F, Lamy E. Association between salivary leptin levels and taste perception in children. J Nutr Metab 2017;2017:7260169.

145. Travers SP, Frank ME. Taste bud leptin: sweet dampened at initiation site. Chem Senses 2015;40:213-5.

146. Katsiougiannis S, Kapsogeorgou EK, Manoussakis MN, Skopouli FN. Salivary gland epithelial cells: a new source of the immunoregulatory hormone adiponectin. Arthritis Rheum 2006; 54:2295-9.

147. Zhao FL, Shen T, Kaya N, Lu SG, Cao Y, Herness S. Expression, physiological action, and coexpression patterns of neuropeptide Y in rat taste-bud cells. Proc Natl Acad Sci U S A 2005;102: 11100-5.

148. Haririan H, Andrukhov O, Bottcher M, Pablik E, Wimmer G, Moritz A, Rausch-Fan X. Salivary neuropeptides, stress, and periodontitis. J Periodontol 2018;89:9-18.

149. La Sala MS, Hurtado MD, Brown AR, Bohorquez DV, Liddle 
RA, Herzog H, Zolotukhin S, Dotson CD. Modulation of taste responsiveness by the satiation hormone peptide YY. FASEB J 2013;27:5022-33.

150. Herness S, Zhao FL. The neuropeptides CCK and NPY and the changing view of cell-to-cell communication in the taste bud. Physiol Behav 2009;97:581-91.

151. Dotson CD, Geraedts MC, Munger SD. Peptide regulators of peripheral taste function. Semin Cell Dev Biol 2013;24:232-9.

152. Acosta A, Hurtado MD, Gorbatyuk O, La Sala M, Duncan D, Aslanidi G, Campbell-Thompson M, Zhang L, Herzog H, Voutetakis A, Baum BJ, Zolotukhin S. Salivary PYY: a putative bypass to satiety. PLoS One 2011;6:e26137.

153. Lu SG, Zhao FL, Herness S. Physiological phenotyping of cholecystokinin-responsive rat taste receptor cells. Neurosci Lett 2003;351:157-60.

154. Herness S, Zhao FL, Lu SG, Kaya N, Shen T. Expression and physiological actions of cholecystokinin in rat taste receptor cells. J Neurosci 2002;22:10018-29.

155. Martin B, Dotson CD, Shin YK, Ji S, Drucker DJ, Maudsley S, Munger SD. Modulation of taste sensitivity by GLP-1 signaling in taste buds. Ann N Y Acad Sci 2009;1170:98-101.

156. Takai S, Yasumatsu K, Inoue M, Iwata S, Yoshida R, Shigemura N, Yanagawa Y, Drucker DJ, Margolskee RF, Ninomiya Y. Glucagon-like peptide-1 is specifically involved in sweet taste transmission. FASEB J 2015;29:2268-80.

157. Ono R. GLP-1 receptor expression in rat major salivary glands and the effects of bilateral maxillary molar extraction on its expression. Kokubyo Gakkai Zasshi 2015;81-82:8-14.

158. Ohta K, Laborde NJ, Kajiya M, Shin J, Zhu T, Thondukolam AK, Min C, Kamata N, Karimbux NY, Stashenko P, Kawai T. Expression and possible immune-regulatory function of ghrelin in oral epithelium. J Dent Res 2011;90:1286-92.

159. Groschl M, Topf HG, Bohlender J, Zenk J, Klussmann S, Dötsch J, Rascher W, Rauh M. Identification of ghrelin in human saliva: production by the salivary glands and potential role in proliferation of oral keratinocytes. Clin Chem 2005;51:9971006.

160. Ventre G, Colonna C, Smith J, Alfano D, Moldow R. Salivary VIP concentrations are elevated in humans after acute stress. Peptides 2013;49:27-31.

161. Sinclair MS, Perea-Martinez I, Abouyared M, St John SJ, Chaudhari N. Oxytocin decreases sweet taste sensitivity in mice. Physiol Behav 2015;141:103-10.

162. Sinclair MS, Perea-Martinez I, Dvoryanchikov G, Yoshida M, Nishimori K, Roper SD, Chaudhari N. Oxytocin signaling in mouse taste buds. PLoS One 2010;5:e11980

163. Martin LE, Nikonova LV, Kay K, Paedae AB, Contreras RJ, Torregrossa AM. Salivary proteins alter taste-guided behaviors and taste nerve signaling in rat. Physiol Behav 2018;184:15061.

164. Seta Y, Kataoka S, Toyono T, Toyoshima K. Expression of galanin and the galanin receptor in rat taste buds. Arch Histol Cytol 2006;69:273-80.

165. Lee RJ, Hariri BM, McMahon DB, Chen B, Doghramji L, Adappa ND, Palmer JN, Kennedy DW, Jiang P, Margolskee $\mathrm{RF}$, Cohen NA. Bacterial d-amino acids suppress sinonasal innate immunity through sweet taste receptors in solitary chemosensory cells. Sci Signal 2017;10:eaam7703.

166. Wang H, Zhou M, Brand J, Huang L. Inflammation and taste disorders: mechanisms in taste buds. Ann N Y Acad Sci 2009; 1170:596-603.

167. Wang R, van Keeken NM, Siddiqui S, Dijksman LM, Maudsley S, Derval D, van Dam PS, Martin B. Higher TNF- $\alpha$, IGF-1, and leptin levels are found in tasters than non-tasters. Front Endocrinol (Lausanne) 2014;5:125.

168. Feng P, Zhao H, Chai J, Huang L, Wang H. Expression and secretion of TNF- $\alpha$ in mouse taste buds: a novel function of a specific subset of type II taste cells. PLoS One 2012;7:e43140.

169. Cohn ZJ, Kim A, Huang L, Brand J, Wang H. Lipopolysaccharide-induced inflammation attenuates taste progenitor cell proliferation and shortens the life span of taste bud cells. BMC Neurosci 2010;11:72.

170. Zhang J, Zhang L, Zhang S, Yu Q, Xiong F, Huang K, Wang CY, Yang P. HMGB1, an innate alarmin, plays a critical role in chronic inflammation of adipose tissue in obesity. Mol Cell Endocrinol 2017;454:103-11.

171. Kloting N, Fasshauer M, Dietrich A, Kovacs P, Schon MR, Kern M, Stumvoll M, Bluher M. Insulin-sensitive obesity. Am J Physiol Endocrinol Metab 2010;299:E506-15.

172. Bar C, Cohen I, Zhao D, Pothula V, Litskevitch A, Koseki H, Zheng D, Ezhkova E. Polycomb repressive complex 1 controls maintenance of fungiform papillae by repressing sonic hedgehog expression. Cell Rep 2019;28:257-66.

173. Wang C, Shan S, Wang C, Wang J, Li J, Hu G, Dai K, Li Q, Zhang X. Mechanical stimulation promote the osteogenic differentiation of bone marrow stromal cells through epigenetic regulation of Sonic Hedgehog. Exp Cell Res 2017;352:346-56.

174. Zhou Q, Guan W, Qiao H, Cheng Y, Li Z, Zhai X, Zhou Y. GATA binding protein 2 mediates leptin inhibition of PPAR $\gamma 1$ expression in hepatic stellate cells and contributes to hepatic 
stellate cell activation. Biochim Biophys Acta 2014;1842:236777.

175. Chen HC, Yang CM, Cheng JT, Tsai KW, Fu TY, Liou HH, Tseng HH, Lee JH, Li GC, Wang JS, Hou YY, Weng TJ, Ger LP. Global DNA hypomethylation is associated with the development and poor prognosis of tongue squamous cell carcinoma.
J Oral Pathol Med 2016;45:409-17.

176. Xie P, Lefrancois P. Efficacy, safety, and comparison of sonic hedgehog inhibitors in basal cell carcinomas: a systematic review and meta-analysis. J Am Acad Dermatol 2018;79:1089100. 